\title{
Power and Identity of the Individual in Contexts of Violence and Trauma
}

\author{
Elizabeth B D Johnson
}

\section{Introduction}

The horrors of the violence of war and the individual's response to extreme conflict have fascinated readers for generations, putting human capability to adapt and survive to the test on the page. The two fictional works "Strange Fruits" by Monica Arac de Nyeko and Unknown Soldier, Vol. 4: Beautiful World written by Joshua Dysart and illustrated by Alberto Ponticelli explore the stories of those living through the hardships of life amidst political conflict involving Lord's Resistance Army (LRA) activity in northern Uganda and neighboring countries. Despite this shared context, these two works tell the experience of the LRA's influence on people's lives from very different perspectives. These points of view are showcased through characters with contrasting access to achieve power and agency in their own lives despite extreme trauma and violence permeating the spaces they interact with and inhabit. The representational strategies employed within each narrative (such as narrative framing, medium-specific elements of storytelling, the splitting of identity, the connection to land in both the physical and spiritual sense, etc.) serve to inform the reader of the effects of violence and injustice on the individual and their everyday life.

Both works dive into the ways that larger violent structures (such as the LRA and corrupted government) rip apart the individual, as well as the various means by which people seek and define strength within these structures. In Unknown Soldier, the agency of the main character, Moses, is characterized by his external power to (attempt to) affect change through physical acts of domination. Contrastingly, the narrator, Lakidi, in "Strange Fruits" performs

Copyright (C) 2020 Elizabeth B D Johnson 
acts of power as an individual through internal battling for possession of her own body and identity. In comparison to Unknown Soldier and its main character, Moses, the character of Lakidi and the representational strategies at work in "Strange Fruits" more effectively construct and represent the civilian experience of the individual's power (or the lack thereof) and the importance of identity in the extreme contexts of war, trauma, and pain.

\section{Background On The LRA}

Both Unknown Soldier and "Strange Fruits" take place amidst the violence of the Lord's Resistance Army's activity in northern Uganda, southern Sudan, and the Democratic Republic of the Congo. Today, the Lord's Resistance Army (LRA) is still active but not considered a threat "from a conventional military standpoint" and is "only a shadow of what it once was" according to Christopher R. Day in "'Survival Mode': Rebel Resilience and the Lord's Resistance Army" (966). The group, led by Joseph Kony, grew out of other rebel groups in northern Uganda in the 1980s as a violent expression of rebellion against the governing powers in the country, specifically President Yuweri Museveni's regime in the case of the LRA. They take refuge in the bush and typically raid readily accessible communities to replenish their supply of food, soldiers (through abduction), and concubines (also through abduction) (Day 969). The LRA is known for its violence against civilians, as the group has "killed more than 100,000 civilians and has displaced hundreds of thousands more across five countries" (Day 966). Kony justifies the LRA's actions and the fear they instill through spiritual and ethnically based methods, to simplify an incredibly complex conflict and rational. As the authors of The Lord's Resistance Army: Myth and Reality, Tim Allen and Koen Vlassenroot, explain, "Kony claimed that Acholi society [, an ethnic group in northern Uganda,] had to be purified by violence, but he has been much more prone to specifically targeting non-combatants, and his forces have specialized in performing shocking atrocities on a few individuals, spreading fear in the population as a whole" (10). This group's activity is the backdrop to both the graphic novel Unknown Soldier and the short story "Strange Fruits."

\section{Unknown Soldier}

The graphic novel as a medium engages with a legacy of "superheroes", which makes it necessary to consider the ethics of translating such sensitive and controversial events in such a spectacular form, as done in the Unknown 
Soldier. In "Some Medium Specific Qualities of Graphic Sequences," Pascal Lefevre attests that drawing style informs the reader of the seriousness with which they should read a story and the level of reality the illustrator and writer want to convey. In this way, drawing style affects the acceptability of the depicted violence in a graphic novel, as well as the ability and preparedness of the reader to bear viewing the violence (16). The drawing style in Unknown Soldier is very realistic with sharp lines that harshen the depiction of characters and events. This style lends itself to harsher content (such as violence) because the lines are so cutting. For the most part, the color scheme in Unknown Soldier is a darker tone, broken up by the aggressive use of red to imply violence, blood, and anxiety in each panel consistent with the continuation of horror and revival trends that are popular in Vertigo comics, as Alicia Decker recounts in "Teaching History with Comic Books: A Case Study of Violence, War, and the Graphic Novel" (173). Through this sharp, realistic style, the reader is invited to engage with the narrative on a serious level and interact critically with the text. Yet, this style simultaneously implies a certain reality alongside the seriousness of the story, and therefore implies a reality of constant, allconsuming violence. The reader is engaged seriously with the violence on the page, which dominates the narrative and in turn dominates the ideas the reader takes away from the narrative.

The role of spectacle is further problematic when working with topics such as African violence because there is such a history of exploitative and harmful stereotypes that have been perpetuated for decades - there is no need to perpetuate those stereotypes any further. Within the story, the individual's agency, as constructed by the formal elements of the medium, is key to determining the ethicality of this story's representation in the medium of the graphic novel. George Gene Gustines quotes Dysart in his "Civil War in Uganda, Illustrated and in Panels" review for the New York Times in 2009: "I witnessed people at the lowest point of their lives, and I came back and turned it into an action-packed war comic. We try our best not to be exploitative, but in my heart I don't know if this is the right way to do it." The series itself was well-received, and it attempts to show more than the singular story of war on an African landscape. The reader sees how life goes on outside of the war, maybe in part defined by it but also very separate. For example, Sera goes to the double wedding ceremony for an Acholi/Christian couple with Momulu (Dysart 37-45), and later on in the novel the reader sees Sera vacationing to see beautiful things in the world that has been so defined by conflict and pain for her. However, the novel is so based in violence with the main character Moses 
being extremely militarized and mythologized. The central focus of the novel is his story, which is problematic in dispelling inaccurate stereotypes of Africa as a violence ravaged continent.

Moreover, the graphic novel as a medium lends itself to the fragmentation of formal aspects of the narrative, such as time and mis-en-page, which further serve to represent the fragmentation of Moses Lwanga's identity in his attempts to achieve conventional strength in the midst of conflict. His dehumanization and weaponization as the Unknown Soldier demonstrate an achieved agency over his body at the cost of the individual himself. Moses's complete erasure of self and descent into the character of the Unknown Soldier is simulated through color, dialogue, and mis-en-page when he cuts off ties for the last time with Sera (Dysart 70-83). The incongruency of who Moses was in the goldtinted past to who he is now is illustrated through the dark-colored panels that overlay and bookend the happy memories, tainting the mood to create an emotional distance between Sera and Moses that mirrors the physical space separating them (Dysart 70). In the following pages, the dark panel of Sera crying in apparent heartbreak as Moses says, "your time with Moses is over" overlaps the brightly colored panel featuring their wedding and a promise of "Forever" (Dysart 72). His breaking of this promise interrupts the wedding panel, encroaching on the memory and overlaying it with the dark-colored, harsh realities of the present. Furthermore, the heightened salience of the red panel on this page, which shows the Unknown Soldier committing a violent act, draws the reader's attention and colors the scene as an explanation for both the past and present - violence triggered the change in the past, and now Moses is choosing violence over life with Sera, which will shape their futures. The fragmentation of past time woven together with the present in these panels, and colored to reflect the shift in tone, represent Moses' death as he is fully weaponized into the Unknown Soldier. His breakdown as an individual follows the breakdown of time as past meets present and is systematically overlaid by the new darkness. He is no longer the man; he is the mission.

Furthermore, Moses' loss of identity as a means to achieve power and complete his mission is complicated by his anonymity, the 'everyman' that he represents when fighting beneath the disguise of bandages. Moses is equated to several conflicting perspectives involved in the war on page 99, which challenge the strict interpretation of perpetrator and victim. The page consists of 5 identical panels stacked vertically with the image of a person (Moses, Moses as the Unknown Soldier, ghost of the original Unknown Soldier, child 
soldier, Joseph Kony) looking straight ahead to the reader while positioned in the same left-side alignment in each panel. This page layout encourages the reader to compare each person to one another, especially following the haunting words that the ghost of the Unknown Soldier (German version) spoke of Joseph Kony: “He sounds... uncomfortably like myself” (Dysart 96). Each person is a victim and a perpetrator in their own way. Moses's identity is confused here due to the 'everyman' quality of his bandaged alter ego, as it is unclear who he is supposed to represent: the victim or the hero or the perpetrator. His multi-identity in militarized form relates to the Kalashnikov history that frames the novel, drawing similarities between Moses as the Unknown Soldier and Kalashnikov's destructive gun. His gained physical prowess cannot coexist alongside Moses as an individual, removing the humanity from his mission. Moses's loss of identity to the anonymity of being the Unknown Soldier separates his mission from its purpose, rendering it meaningless.

\section{Strange Fruits}

The lyrics to the song "Strange Fruits", popularized by Billie Holiday, frames Arac de Nyeko's short story, connecting the rich history of resistance in the American South to the rural Northern Ugandan struggle to survive LRA activity and corrupt government forces. The sweet and beautiful are juxtaposed to violence in both Billie Holiday's song "Strange Fruits" and Arac de Nyeko's short story "Strange Fruits." The poplar trees from Holiday's song resonate in the short story as Mwaka's beloved mango tree. It was symbolic of safety and family: the mangos were always on Mwaka's breath, the tree supported the family with its mangos, protected Mwaka's grandfather during his life, and connected the family to lost relatives. The lyrics to Holiday's song precede the narrative, foreshadowing the deadly significance of the tree:

Southern trees bear strange fruit,

Blood on the leaves and blood at the root,

Black bodies swinging in the southern breeze,

Strange fruit hanging from the poplar trees. (Arac de Nyeko 1)

Mwaka's death is foreshadowed in the "blood on the leaves" and blood on his breath after returning from the rebel group to Lakidi. His spirit and the person he was before being taken are gone, and there is no way to return. The mango tree as a death site, in connection with the "strange fruit", symbolizes 
more than the death of a man, but the destruction of a family as well. Tradition and security died there.

Furthermore, the song evokes strong images of mutilation of the black body as politically charged injustice, and resistance against brutality as identity building. The historical significance of Holiday's "Strange Fruits" as a song of resistance in the American South supplements the binary of institution versus individual. "Black bodies" are politicized in their mutilation. Mwaka is beaten and hanged on the tree in connection with the lynchings that Holiday's song protests. He is made an example of. As Sofia Ahlberg asserts in "Women and War in Contemporary Love Stories from Uganda and Nigeria," "the erotic is coupled with brutality" (413). Lakidi is brutally raped in front of her child as a strategy of war (by the government forces) to dominate a defiant resister. However, in this physically powerless state, Lakidi attempts to return some agency to herself by defining her identity: "She cannot fight off the soldier who defiles her and causes her unforgivable physical and emotional injury, but by reminding herself who she is, and gaining possession of her body once again, she rises above the crime" (Ahlberg 414). Her mental resistance against the brutal crimes committed against her return to her the control and agency over her own story that were stolen. Opposite to Moses in the Unknown Soldier, Lakidi finds strength to survive within the contexts of extreme trauma and pain through the capturing of identity rather than the dispelling of it.

Moreover, Arac de Nyeko employs earth imagery and metaphor to create a powerful source of identity for the individual and community. In "Writing on the Soil: Literature's Influence on African Land Rights", Ng'ang'a Muchiri argues that land "came to represent both a life generating potential and a threatening force - and in either case, the patriarchal postcolonial state sought to dominate and control" (Muchiri 1). Nature is power in Arac de Nyeko's short story, both benevolent and threatening. As a benevolent figure, the land supports family and fond early memories for Lakidi. Her relationship with Mwaka is defined in nature - his mango breath, their first intimate night shared under the moon, their pact made over rose-thorn-pricked fingers. Furthermore, Lakidi understands external threats in terms of nature: the rebels as "hailstorms flung by lightning" (Arac de Nyeko 11), the smell of rot that came with the rebels, the leeches and lost souls of the Aringa River as result of the war, her dead husband as a "strange fruit, waiting to be plucked" (Arac de Nyeko 35), the grip of her attacker like a waterfall, the rape as snake venom. Nature brings Lakidi understanding of her situation and relationships, 
translating every experience into an identifiable format she can relate to, even if it is outside of her control.

As a community, natural setting informs social constructs of superiority and inferiority relating to urban versus rural settings. Muchiri contends that Arac de Nyeko exposes urban snobbery from Kampala and reveals the country "as both remotely idyllic and savagely violent" (170). Arac de Nyeko does not view the reality of the country through the rose-colored glasses but rather presents it realistically. The effect of violent military structures in everyday life appears at the natural level to convey community hardship. Muchiri describes these militaristic effects on the Aringa River by articulating, "The armed conflict between the LRA and the Ugandan State has turned the river into a repository of death, loss and unvoiced mourning" (179). Communal suffering is understood through the presence of leeches in the body of water that holds communal memory. The parasites are quite literally sucking the community dry, the way that the war is tearing apart families and perpetuating violence in characters' lives. Even beyond the understanding of the physical world, nature informs the way Lakidi interacts with the spiritual. In an attempt reunite with Mwaka after he is abducted by the rebel group, Lakidi went "to lay four large stones in the cemetery to invite Mwaka's spirit back home to rest with his ancestors under the big kituba tree" (Arac de Nyeko 16). Nature allows Lakidi to reconnect with those and that which she has lost, as well as allows her to support her family despite the physically dominant structures that separate them. Trees in particular reoccur throughout the short story to symbolize greater structures of power and connection, such as love, family, cross-cultural understanding of resistance and survival, beauty, life, and death. Nature gives Lakidi the tools to express agency in how she wishes to interact with members of her community and loved ones.

Moreover, the earth and nature are essential tools for Lakidi to reclaim authority over self and construct identity, which allows her to claim power over her own body and mind despite the violent forces working against her. After the rape, Lakidi's body merges with the earth - "The red earth has blended with my naked thighs. My breasts point up to the heavens like two small anthills" (Arac de Nyeko 37). She sinks into the ground and becomes insignificant. At first, the ground is escape - escape from her body and from self. Equating the land with her own physical form allows Lakidi to first distance herself from "the lingering filth in [her] depth" (Arac de Nyeko 35). She reclaims what she can of a physical sense of safety through the earth. Then, Lakidi reminds 
herself, "my name is Lakidi Sofia. I am Stone. I am warmth. I am Sky" (Arac de Nyeko 35). Lakidi becomes nature, becomes power. She adopts the qualities of the daughter of the moon that she has looked up to her entire life and with whom she has had an intimate friendship. Lakidi takes on the identities she prescribed to Nyadwe (the moon's daughter): "Nyadwe was earthquake. Nyadwe was lightning. Nyadwe was time. Nyadwe was power" (Arac de Nyeko 17). The language Lakidi uses to describe Nyadwe here is very ritualistic, repetitive like a chant, starting each sentence with "Nyadwe was". This language mirrors the way she describes herself in the ending lines, repeating the words "I am". Lakidi becomes so large and all-absorbing that she is both the earth and the sky. Ahlberg concludes, "While they do not necessarily live 'happily ever after,' it is also true that the female characters refuse to be victimized" (409). Refusing victimhood, Lakidi comes back to herself and overcomes the trauma through her individual identification rooted in the earth and the force of nature. She herself becomes a force of nature.

Similarly, the role of love in Lakidi's narrative is central to her ability to survive traumatic situations and settings. Ahlberg explains that, "As a means of self-determination, a way out of victimhood and torment... love also becomes a powerful means of political and social change" (409). Love of Mwaka allows Lakidi to take agency over her love life and living situation despite her mother's disapproval. Alberg informs the way that love performs political work in "Strange Fruits", "Arac de Nyeko uses the narrative of romance to "personalize" crimes against humanity" (413). The black body hanging from the tree, as referenced in both the historical context of lynchings in the American South in Holiday's song "Strange Fruits" and the character of Mwaka in Arac de Nyeko's short story, is humanized through the love of Lakidi. She still views Mwaka as her "defeated warrior", a person she had been willing to risk her own safety and the safety of her child to house and take care of. Though their relationship is strained, love is what pushes Lakidi to stay in the country even as her mother pressures her to return to the city with her child. It is also love that brings Lakidi back to herself after being brutally raped. Her child, Piloya, calls her name, and it is one of the few sounds that make it to Lakidi's ears, piercing through the deafening silence that followed the assault. 


\section{Conclusion}

In comparison to the main character Moses and narrative of the Unknown Soldier, Lakidi's character and the representational strategies at work in "Strange Fruits" more effectively construct and represent the civilian experience of the individual's power (or the lack thereof) and the importance of identity in the extreme contexts of war, trauma, and pain. Through the single perspective of Lakidi Sofia, "Strange Fruits" details the birth and destruction of a family as they try to stand against the pressure of LRA activities while inhabiting an essentially powerless position in society. The reader is exposed to the family's powerlessness as they are subjected to the rebel group's activities and goals as well as the whims of the government. On the other hand, Unknown Soldier is experienced through several character perspectives (Moses and Sera) that objectively seem to be able to choose whether they involve themselves in the conflict or not, yet subjectively are unable to step away from this conflict that is destroying their relationships and everyday lives.

"Strange Fruits" utilizes narrative framing to align the history of resistance in the American south with the struggle of Northern Ugandans (living in rural areas) to survive LRA activity and corrupted government forces. This connection evokes the ideas of politicized black bodies and resistance as identity building in the short story by Arac de Nyeko. Moreover, Arac de Nyeko employs earth imagery and metaphor to create a powerful source of identity for the individual and community. Lakidi uses land and nature to reclaim authority over self and construct identity, which allows her to claim power over her own body and mind despite the violent forces working against her. However, the framing of the graphic novel Unknown Soldier further serves to lodge the narrative in ideas of widespread violence and dispels the individual from the reader's understanding of the Unknown Soldier as an overly weaponized figure. The fragmentation of the Unknown Soldier's identity is represented in the formal aspects of fragmented narrative typical in the medium of graphic novels. His achieved bodily agency comes at the cost of personal identity. Furthermore, Moses's identity is confused due to the 'everyman' quality of his bandaged alter ego, as it is unclear who he is supposed to represent: the victim or the hero or the perpetrator. His multi-identity in militarized form relates full circle to the Kalashnikov history that frames the novel, drawing similarities between Moses as the Unknown Soldier and Kalashnikov's destructive gun. 
Unknown Soldier, vol. 4: Beautiful World is less effective at demonstrating the individual's experience of constructing identity and individual power amidst larger structures of war, trauma, and pain due to the Moses's consistent pursuit throughout the graphic novel to erase the individual from himself in favor of physical prowess. Lakidi of Monica Arac de Nyeko's "Strange Fruits" is able to more effectively represent the individual's struggle to achieve personal agency because she takes the opposite approach. Lakidi seeks the power of individual identity which provides her personal agency and power even when she has been physically dominated.

\section{Works Cited}

Ahlberg, Sofia. "Women and War in Contemporary Love Stories from Uganda and Nigeria." Comparative Literature Studies, vol. 46, no. 2, 2009, pp. 407-424.

Allen, Tim, and Koen Vlassenroot. The Lord's Resistance Army: Myth and Reality / Edited by Tim Allen and Koen Vlassenroot. Zed Books, 2010.

Cohn, Jesse. "Mise-En-Page: A Vocabulary for Page Layouts." Teaching the Grapbic Novel, by Stephen Ely. Tabachnick, The Modern Language Association of America, 2009, pp. 44-57.

Day, Christopher R. “'Survival Mode': Rebel Resilience and the Lord's Resistance Army.” Terrorism and Political Violence, vol. 31, no. 5, 2019, pp. 966-986.

Decker, Alicia C., and Mauricio Castro. "Teaching History with Comic Books: A Case Study of Violence, War, and the Graphic Novel.” The History Teacher, vol. 45, no. 2, 2012, pp. 169-187.

Dysart, Josh., et al. Unknown Soldier. 4, Beautiful World / Joshua Dysart, Writer ; Alberto Ponticelli, Rick Veitch, Illustrators. DC Comics, 2011.

Gustines, George Gene. "Civil War In Uganda, Illustrated And in Panels." The New York Times, vol. 158, no. 54765, 2009.

Lefèvre, Pascal. "Some Medium-Specific Qualities of Graphic Sequences." Sub-Stance, vol. 40, no. 1, 2011, pp. 14-33.

Monica Arac de Nyeko, "Strange Fruits.” Ed. Violet Barungi. Gifts of Harvest. Kampala: Femrite, 2006. 1 - 38.

Muchiri, Ng'ang'a, et al. Writing on the Soil: Literature's Influence on African Land Rights, 2015, pp. ProQuest Dissertations and Theses. 